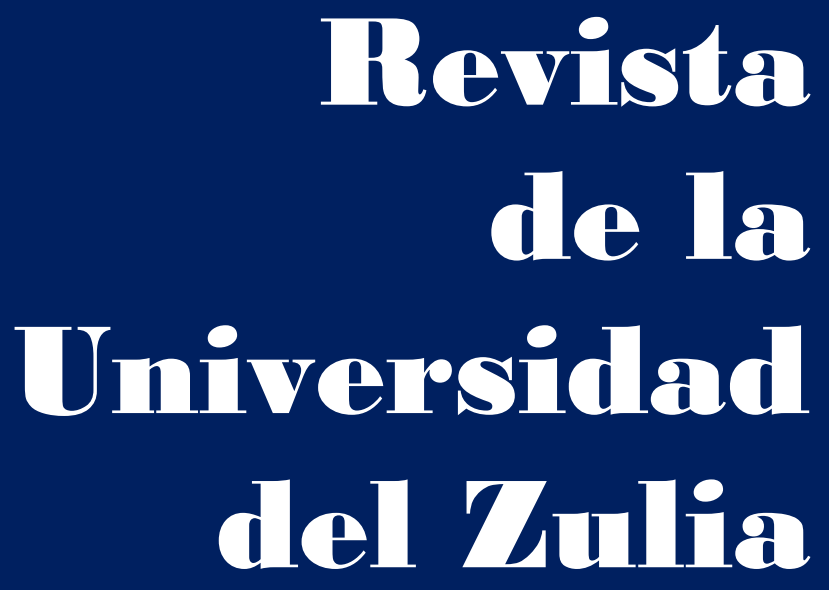

Fundada en 1947

por el Dr. Jesús Enrique Lossada

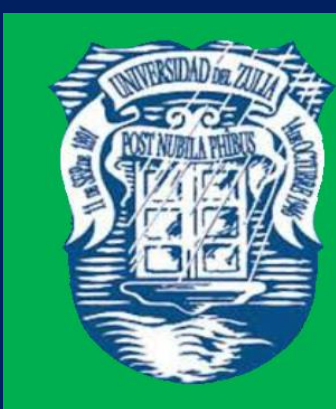

Ciencias del

Agred

Ingemieria

y Teenología
Añต 12 No 32

Enero - Abril 2021

Tercera Época

Maracailbo-Venezuela 


\title{
Development of a methodology for determining the financial security of rural areas
}

\author{
Gamlet Y. Ostaev * \\ Inna A. Mukhina ** \\ Elena V. Alexandrova *** \\ Elena V. Belokurova $* * * *$ \\ Lyudmila G. Titova *****
}

\begin{abstract}
The current state of most of Russia's territories is such that the development rates of specific regions remain low. This phenomenon does not allow for sustainable long-term economic security. Therefore, it is necessary to develop measures to determine the financial stability of the individual regions and territories of the country for the purposes of their development under current conditions. In this sense, the real problem is to determine the financial indicators to assess the economic security of rural areas. This can be achieved through the formation of a scientifically based action algorithm aimed at improving the situation in rural areas. The research topic is the formation of a system to identify financial indicators in the evaluation of the economic security of rural areas. The theoretical and practical significance of solving problems related to the achievement of sustainable development in rural areas determined the choice of goals, objectives, object and theme of this study. Based on the above, the object of the study is the municipal budget and agricultural enterprises as the basis for the development of rural areas. The purpose of the study is to establish the methodology for evaluating financial security in rural areas as a financial management instrument at the municipal level. The following tasks were implemented in the course of the study: selection of financial indicators based on official and expert sources; Foundation of the mathematical apparatus to calculate the comprehensive and private indicators of the financial security of the territory using the principles of qualimetry (the science of measuring quality). The proposed methodology allows to systematize the financial and economic indicators, it serves as the main calculation of the financial and economic security of the Udmurt Republic; the methodology can also be applied to other rural areas of the country.
\end{abstract}

KEY WORDS: monitoring, financial security, rural areas, assessment.

* Candidate of Economic Sciences, Associate Professor of Accounting, Finance and Audit, Izhevsk State Agricultural Academy, 426069, Izhevsk, Studencheskaya Street, 1l. Spin-code: 3674-4120. ORCID: https://orcid.org/0000-0003-0869-7378.

** Candidate of Economic Sciences, Associate Professor of the Department of Economics of the AgroIndustrial Complex, Izhevsk State Agricultural Academy, 426069, Izhevsk, Studencheskaya Street, 1l. The Udmurt State University 426034, Russia, Izhevsk, Universitetskaya Street, 1/4. ORCID: https://orcid.org/ 0000-0003-1789-7275.

*** Candidate of Economic Sciences, Associate Professor of the Organization of Production and Economic Analysis, Izhevsk State Agricultural Academy, 426069, Izhevsk, Studencheskaya Street, 11. Spin-code: 89287417. ORCID: https://orcid.org/ 0000-0002-8682-2755.

**** Candidate of Economic Sciences, Associate Professor of the Tyumen Industrial University, a branch in the city of Nizhnevartovsk, 628600, Khanty-Mansi Autonomous district, Nizhnevartovsk, Lenin Street., 2 con.9. Spin-code: 6442-4600. ORCID: https://orcid.org/ 0000-0003-0809-4446.

***** Doctor of Political Sciences, Professor of the Department of social and political theories, faculty of social and political Sciences, P.G. Demidov Yaroslavl State University, 150003, Yaroslavl, Sovetskaya Street, 14. Spincode: 9863-6988. ORCID: https://orcid.org/ 0000-0003-4168-7753.

Recibido: 30/10/2020

Aceptado: 01/12/2020 


\section{Desarrollo de una metodología para determinar la seguridad financiera de las zonas rurales}

RESUMEN

El estado actual de la mayoría de los territorios de Rusia es tal, que las tasas de desarrollo de las regiones específicas se mantienen en un nivel bajo. Este fenómeno no permite lograr una seguridad económica sostenible a largo plazo. Por lo tanto, es necesario desarrollar medidas para determinar la estabilidad financiera de las regiones y territorios individuales del país a los efectos de su desarrollo en las condiciones actuales. En este sentido, el problema real es determinar los indicadores financieros para evaluar la seguridad económica de las zonas rurales. Esto se puede lograr a través de la formación de un algoritmo de acciones con base científica orientada a mejorar la situación en las zonas rurales. El tema de la investigación es la formación de un sistema para identificar indicadores financieros en la evaluación de la seguridad económica de las áreas rurales. La trascendencia teórica y práctica de la resolución de problemas relacionados con el logro del desarrollo sostenible de las zonas rurales determinó la elección de metas, objetivos, objeto y tema de este estudio. Con base en lo anterior, el objeto del estudio es el presupuesto municipal y las empresas agrícolas como base para el desarrollo de las zonas rurales. El propósito del estudio es fundamentar la metodología de evaluación de la seguridad financiera de las zonas rurales como instrumento de gestión financiera a nivel municipal. Las siguientes tareas fueron implementadas en el curso del estudio: selección de indicadores financieros basados en fuentes oficiales y expertas; fundamentación del aparato matemático para calcular los indicadores integrales y privados de la seguridad financiera del territorio utilizando los principios de la cualimetría (la ciencia de medir la calidad). La metodología propuesta permite sistematizar los indicadores financieros y económicos, sirve como el cálculo principal de la seguridad financiera y económica de la República de Udmurt; la metodología también se puede aplicar a otras áreas rurales del país.

PALABRAS CLAVE: seguimiento, seguridad financiera, áreas rurales, evaluación.

\section{Introduction}

Financial security is one of the most important components of the economic security of rural areas (Alborov and Kontsevoy, 2016). The main regulatory documents regulating issues of economic security and financial security can be considered: the Constitution of the Russian Federation (Articles 74, Article 75); Decree of the President of the Russian Federation of May 13, 2017 No. 208 "On the Strategy of Economic Security of the Russian Federation for the Period until 2030 of the year".

Considering the level of the municipality, we turned to the Budget Code, which clearly defines the budgetary powers of municipalities (Alekseeva, 2020; Kondratyev et al., 2019). 
The executive authorities of districts, cities, urban districts, rural and settlement administrations that ensure (within the framework of the powers granted) the implementation of a unified state financial policy and carry out general management of financial resources in the territory are called financial bodies of the municipalities of the Russian Federation (Botkin et al., 2020).

They are part of the structure of the executive authorities of municipalities and are an important component of the unified system of state financial management bodies. They act in accordance with the provisions approved by the head of the administration of the relevant municipality (Gogolev et al., 2020).

The main tasks of state bodies carrying out financial activities at the level of municipalities of the Russian Federation:

1) drawing up a draft budget;

2) execution of the budget of the municipal formation (Kontsevaya, 2017; Ostaev et al., 2019)

\section{Methodology}

The development of the world and national economy in modern conditions is characterized by multiple transition processes, accompanied by both local and global crises (Endovitsky et al., 2019; Krivorotov et al., 2015).

Quite a lot of attention is paid to the issues of assessing the financial security of the country and the region, but there is practically no serious research devoted to the financial security of municipalities and, in particular, rural areas (Kondratiev et al., 2020; Molchan et al., 2017).

The starting point here can be the system of Monitoring and assessing the quality of municipal finance management, which is aimed at creating prerequisites for increasing the efficiency of local government bodies by creating incentives for the development of the level of financial management in public law formations of local importance (Mukhin and Mukhin, 2018; Mukhin et al., 2020).

These prerequisites are tasks, the solution of which is provided by the system for monitoring and assessing the quality of financial management (Figure 1). 


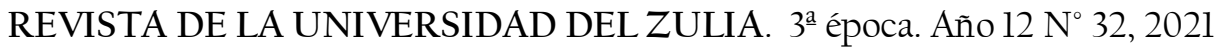

Gamlet Y. Ostaev et al. // Development of a methodology for determining the financial security ... 70-86

DOI: http://dx.doi.org/10.46925//rdluz.32.06

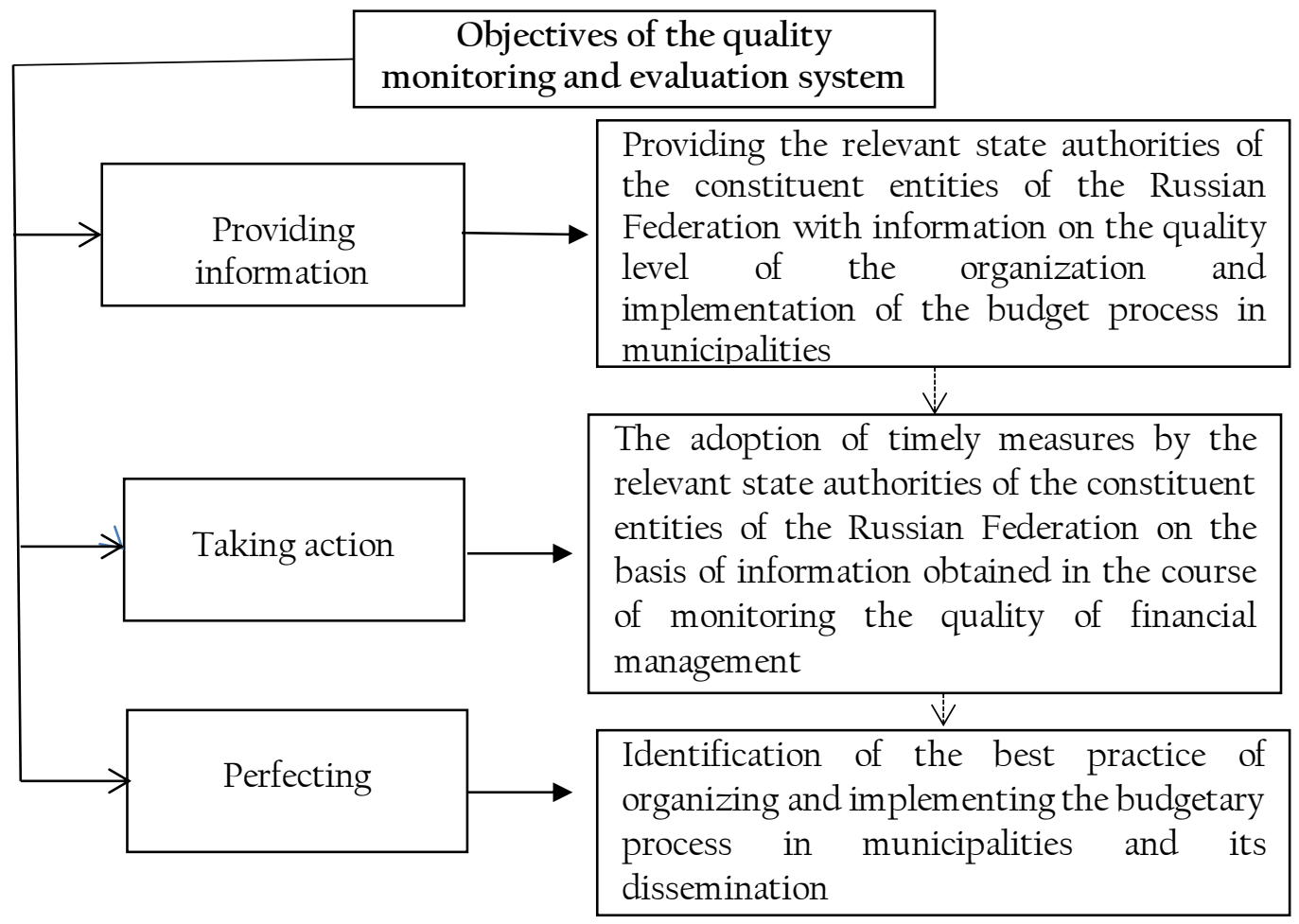

Figure 1- Tasks, the solution of which is provided by the system for monitoring and assessing the quality of financial management (authoring)

We examined the possibilities of developing a financial security system for rural areas, taking into account the regulatory and statistical framework (Molchan et al., 2020).

After evaluating the accumulated experience in managing municipal rural areas, we proposed a systematization of indicators of economic development, and the calculation of integral and private indicators of financial security of the territory using the principles of qualimetry (Mukhina, 2018; Ostaev et al., 2018).

The technique includes the following steps:

Stage 1. Selection and calculation of the main indicators of the economic development of rural areas, including financial ones.

It should be borne in mind:

a) we purposefully study economic aspects, not including social, environmental indicators, etc., based on the purpose of the study;

b) information is used only from official sources; therefore, it is of an aggregated nature. There are the following disadvantages: there is no accounting for more detailed aspects of the economic activity of each economic entity; the set of indicators does not allow studying the business and financial activity of economic entities. 
c) the set of indicators should take into account the specifics of agricultural (agricultural) production; therefore, information is used on the forms of reporting on the financial and economic status of producers of the agro-industrial complex (agriculture) (Markovina et al., 2020; Mukhina et al., 2020).

Stage 2. Quantitative and qualitative assessment of economic security by comparative assessment of actual data with threshold values and desired development trends from the standpoint of the ability of the territory's economy to sustainable growth.

The partial and integral coefficients of economic security are determined (Kontsevaya et al., 2019; Frantsisko et al. 2020).

Stage 3. Revealing the directions of economic threats by the levels of the system of indicators, including particular criteria (Sheremet, 2009).

A system of scales is proposed that indicates the level of financial security stability (Figure 2).

Stage 4. Substantiation of recommendations to improve economic security (Endovitsky and Durakova, 2018).

The descriptive method was applied during the study; this method is a system of procedures for collecting, primary analysis and presentation of data and their characteristics.

2. Results and discussion

The algorithm for constructing a development system, and the calculation of integral and private indicators of the financial security of the territory should take into account different indicators.

First stage. Selection of the main indicators of financial and economic development of rural areas.

The group financial safety factor will accordingly be calculated for each group.

Group l - indicators of the quality of municipal finance management.

In this group of indicators, we select summary indicators in the areas determined by the Monitoring Methodology. 


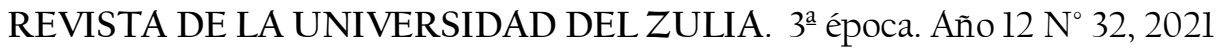

Gamlet Y. Ostaev et al. // Development of a methodology for determining the financial security ... 70-86

DOI: http://dx.doi.org/10.46925//rdluz.32.06

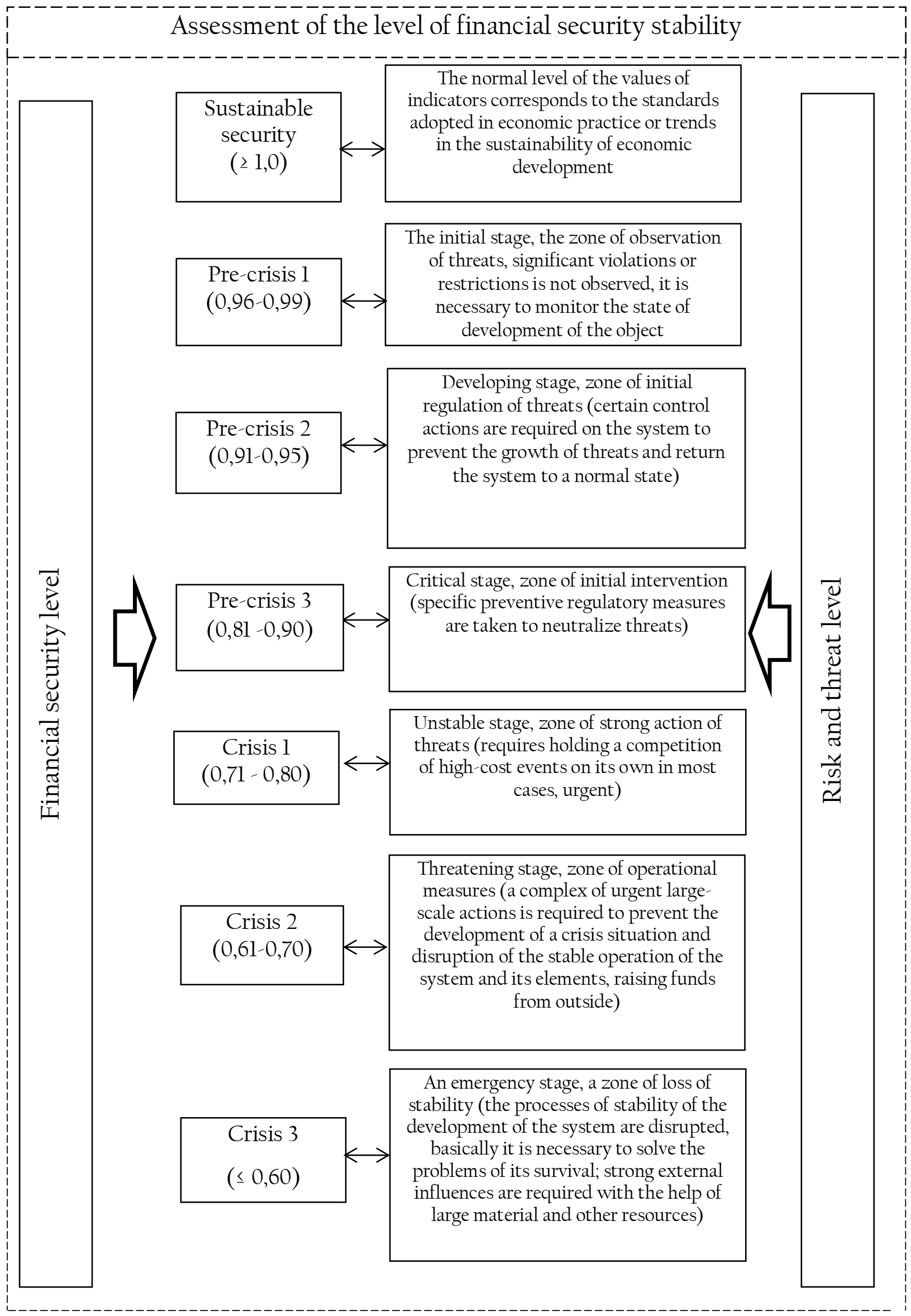

Figure 2 - Scaling the level of financial security stability (author's development) 
Group 2 - indicators of economic development.

In this group, the emphasis is on financial indicators and objects of taxation.

Group 3 - financial results of business activities of large and medium-sized organizations.

The peculiarity of this group is that indicators are selected that characterize the value of the property of business entities, and some indicators of the financial condition of organizations in the region, which are presented in the official reporting, as well as the author's calculations of the financial condition of business entities.

Group 4 - indicators of the efficiency of agricultural production.

The indicators characterizing the financial and production results and the results of the effectiveness of state support for 2016-2018 were selected based on the data of financial statements of 17 farms in the Balezinsky district of the Udmurt Republic (Table 1).

Table 1 - Indicators for calculating the financial security ratios of rural areas on the example of Balezinsky district

\begin{tabular}{|l|c|c|c|c|}
\hline \multicolumn{1}{|c|}{ Name } & \multicolumn{1}{|c|}{2016} & 2017 & 2018 \\
\hline \multicolumn{3}{|c|}{ Group I "Indicators of the quality of municipal finance management" } \\
\hline $\begin{array}{l}\text { l.l. Indicators characterizing the quality of budget } \\
\text { planning }\end{array}$ & 11,3542 & 11,6508 & 9,3219 \\
\hline $\begin{array}{l}\text { l.2. Indicators characterizing the quality of budget } \\
\text { execution }\end{array}$ & 11,3376 & 14,717 & 12,7416 \\
\hline $\begin{array}{l}\text { l.3. Indicators characterizing the quality of debt } \\
\text { management }\end{array}$ & 10,9185 & 11,9256 & 11,9186 \\
\hline $\begin{array}{l}\text { l.4. Indicators characterizing the quality of } \\
\text { municipal property management and the provision } \\
\text { of municipal services }\end{array}$ & 7,1874 & 8,3568 & 8,4167 \\
\hline $\begin{array}{l}\text { l.5. Indicators characterizing the degree of } \\
\text { transparency of the budget process }\end{array}$ & 4,3124 & 5,5868 & 4,537 \\
\hline $\begin{array}{l}\text { l.6. Indicators characterizing the implementation of } \\
\text { the decrees of the President of the Russian } \\
\text { Federation of May 7, 2012 }\end{array}$ & 7,1529 & 5,5694 & 7,7504 \\
\hline $\begin{array}{l}\text { l.7. Indicators characterizing the organization of } \\
\text { financial control and audit }\end{array}$ & 7,6985 & 7,2013 & 9,9993 \\
\hline
\end{tabular}




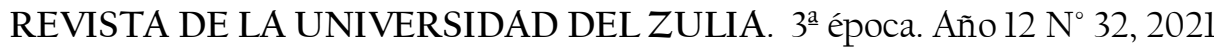

Gamlet Y. Ostaev et al. // Development of a methodology for determining the financial security ... 70-86

\begin{tabular}{|c|c|c|c|}
\hline \multicolumn{4}{|c|}{$\begin{array}{c}\text { Group } 2 \text { "Indicators of economic development of the municipality (financial results } \\
\text { and objects of taxation)" }\end{array}$} \\
\hline $\begin{array}{l}\text { 2.l. The ratio of the revenue and expenditure parts of } \\
\text { the municipal budget }\end{array}$ & 0,97 & 0,98 & 1,01 \\
\hline $\begin{array}{l}\text { 2.2. The share of tax and non-tax revenues of the } \\
\text { local budget (excluding tax revenues according to } \\
\text { additional deduction rates) in the total volume of the } \\
\text { municipal budget's own revenues (excluding } \\
\text { subventions), \% }\end{array}$ & 50,52 & 45,15 & 55,15 \\
\hline $\begin{array}{l}\text { 2.3. Share of fixed assets of organizations of } \\
\text { municipal form of ownership that are in the stage of } \\
\text { bankruptcy in fixed assets of organizations of } \\
\text { municipal form of ownership (at the end of the year } \\
\text { at full book value), } \%\end{array}$ & 0,00 & 0,00 & 0,00 \\
\hline $\begin{array}{l}\text { 2.4. The volume of investments in fixed assets } \\
\text { (excluding budget funds) per capita, rubles }\end{array}$ & 4515,60 & 7817,71 & 4840,88 \\
\hline $\begin{array}{l}\text { 2.5. The share of the area of land plots that are } \\
\text { objects of taxation by land tax in the total area of the } \\
\text { territory of the urban district (municipal district), \% }\end{array}$ & 25,39 & 25,31 & 25,70 \\
\hline $\begin{array}{l}\text { 2.7. Average monthly nominal accrued wages of } \\
\text { employees of large and medium-sized enterprises, } \\
\text { rubles }\end{array}$ & 19608,90 & 21511,80 & 24358,60 \\
\hline \multicolumn{4}{|c|}{$\begin{array}{c}\text { Group } 3 \text { "Financial indicators of entrepreneurial activity of large, medium-sized } \\
\text { organizations and small enterprises" }\end{array}$} \\
\hline $\begin{array}{l}\text { 3.1. Amount of funds allocated to support SMEs, } \\
\text { thousand rubles }\end{array}$ & 3850 & 56346,4 & 80308 \\
\hline $\begin{array}{l}\text { 3.2. The value of the property of organizations not } \\
\text { related to small businesses, million rubles }\end{array}$ & 1965,6 & 2039,0 & 1812,9 \\
\hline $\begin{array}{l}\text { 3.3. Capital and reserves of organizations not related } \\
\text { to small businesses, million rubles }\end{array}$ & 975,4 & 1070,6 & 1179,7 \\
\hline $\begin{array}{l}\text { 3.4. Balanced financial result (profit minus loss) of } \\
\text { organizations' activities, million rubles }\end{array}$ & 61,7 & 65,6 & 34,9 \\
\hline $\begin{array}{l}\text { 3.5. Share of unprofitable organizations that are not } \\
\text { small businesses, } \%\end{array}$ & 25,0 & 14,3 & 46,2 \\
\hline $\begin{array}{l}\text { 3.6. The amount of losses incurred by organizations } \\
\text { other than small businesses, million rubles }\end{array}$ & 23,6 & 53,6 & 44,0 \\
\hline
\end{tabular}




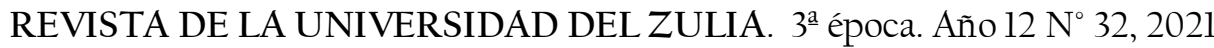

Gamlet Y. Ostaev et al. // Development of a methodology for determining the financial security ... 70-86

DOI: http://dx.doi.org/10.46925//rdluz.32.06

\begin{tabular}{|c|c|c|c|}
\hline $\begin{array}{l}\text { 3.7. The excess of accounts payable over accounts } \\
\text { receivable as a percentage of organizations } \\
\text { receivable, } \%\end{array}$ & 42,2 & 68,4 & 39,0 \\
\hline $\begin{array}{l}\text { 3.8. Costs for the production and sale of sold goods, } \\
\text { products, works, services of organizations not } \\
\text { related to small businesses, per } 1 \text { ruble of sales } \\
\text { proceeds, rubles }\end{array}$ & 1167 & 1232 & 1193 \\
\hline $\begin{array}{l}\text { 3.9. Profitability of sold goods, products, works, } \\
\text { services of organizations, } \%\end{array}$ & 4,0 & 8,0 & 0,7 \\
\hline 3.10. Profitability of all assets of organizations, $\%$ & 3,1 & 3,2 & 1,9 \\
\hline 3.1l. Organizational autonomy ratio & 49,6 & 52,5 & 65,1 \\
\hline $\begin{array}{l}\text { 3.12. Coefficient of provision with own working } \\
\text { capital of organizations }\end{array}$ & $-3,2$ & 9,5 & 27,2 \\
\hline 3.13. Current liquidity ratio of organizations & 131,4 & 162,9 & 199,5 \\
\hline \multicolumn{4}{|c|}{4 group "Financial indicators of the efficiency of agricultural production" } \\
\hline $\begin{array}{l}\text { 4.l. Ratio of revenue from the total cost of milk } \\
\text { production and sales, } \%\end{array}$ & 108,8 & 115,3 & 108,2 \\
\hline $\begin{array}{l}\text { 4.2. The ratio of proceeds from the total cost of } \\
\text { production and sale of meat, } \%\end{array}$ & 71,0 & 74,8 & 63,0 \\
\hline $\begin{array}{l}\text { 4.3. Agricultural products in all categories of farms } \\
\text { in the district, million rubles }\end{array}$ & 2598 & 2743 & 2717 \\
\hline $\begin{array}{l}\text { 4.4. Share of profitable agricultural organizations in } \\
\text { their total number }\end{array}$ & 88,24 & 82,35 & 76,47 \\
\hline 4.5. Profit before tax per employee, thousand rubles & 24,9 & 40,7 & 11,0 \\
\hline 4.6. Taxes paid per 1 ha $x$-lands, thousand rubles & 0,79 & 0,71 & 0,74 \\
\hline $\begin{array}{l}\text { 4.7. Agricultural products sold per } 1 \text { ruble of state } \\
\text { support, rubles }\end{array}$ & 9,48 & 11,36 & 10,9 \\
\hline 4.8. Profit volume for 1 ruble of state support, rubles & 0,38 & 0,68 & 0,17 \\
\hline
\end{tabular}

*Authoring

Second stage. Quantitative and qualitative assessment of economic security by comparative assessment of actual data with threshold values and desired development trends from the standpoint of the ability of the territory's economy to sustainable growth. 
We apply a comparative assessment methodology (system-integration approach) based on qualimetry methods at this stage.

Financial (economic) security is presented in the form of a hierarchical structure ("tree of properties"), at the highest level of which is the integral indicator, and at the lowest level are the private indicators (coefficients).

The specific thresholds used in assessing the economic security of a country and regions are not suitable for the municipal level. In our case, we work taking into account the desired development trend from the standpoint of the ability of the territory's economy to sustainable growth.

Assessment method:

1. The integral coefficient of financial security stability $\mathrm{K}_{\text {fin_security }}$ is determined by the weighted sum formula:

$$
\mathrm{K}_{\text {fin_security }}=\sum_{i=1}^{n} K_{j} \cdot B_{j}
$$

where $\mathrm{k}_{\mathrm{j}}$ is the financial safety factor for the $\mathrm{j}$-th group;

$B_{j}$ is weight of financial security for the $j$-th group;

$n$ is the number of groups.

2. We determine the coefficient $\mathrm{K}_{j}$ for each $\mathrm{j}$-th group We use the harmonic mean formula to determine the indicator:

$$
\mathrm{K}_{\mathrm{j}}=\sqrt[n]{\prod K_{i j}}
$$

where $\kappa_{i j}$ is the private coefficient of financial security in the $j$-th direction in the $i$-th parameter;

$\mathrm{n}$ is the number of parameters;

3. Selection of values of weighting factors.

In our opinion, the group of indicators of the financial security of agricultural production should be given greater importance in determining the financial security of rural areas. 
REVISTA DE LA UNIVERSIDAD DEL ZULIA. 3ª época. Año 12 N 32, 2021

Gamlet Y. Ostaev et al. // Development of a methodology for determining the financial security ... 70-86

DOI: http://dx.doi.org/10.46925//rdluz.32.06

The following weighting factors were selected in agreement with the employees of the Balezinsky District Agriculture Department (Head of the Agriculture Department, Head of the Production and Technological Department, Head of the Rural Development Sector):

Group $1=0.2$

Group $2=0.2$

Group $3=0.2$

Group $4=0.4$

The sum of the weights is 1 .

4. We calculate the partial coefficients taking into account the characteristics of improving (strengthening) financial security

4.1. The variant when the desired trend is an increase in the private parameter. For example, all indicators of group 1 , the product profitability indicator (3.9) will be direct, that is, their increase means improved financial security and reduce risks. The coefficient is calculated by the ratio of the reporting period to the base period. We compare with the previous year on the principles of sustainability:

$$
\mathrm{K}_{\mathrm{ij}}=\frac{\text { Indicator value } \mathrm{i}_{\text {} 2017}}{\text { Indicator value }_{\mathrm{i}_{\_} 2016}}
$$

4.2. The variant when the desired trend is a decrease in the value of a particular parameter. For example, the share of unprofitable organizations (3.5), costs per 1 ruble. revenues (3.8) will be reversed, that is, their increase means a decrease in financial security. The calculation formula is:

$$
\mathrm{K}_{\mathrm{ij}}=\frac{\text { Indicator value } \mathrm{i} \_2016}{\text { Indicator value }_{\mathrm{i} \_2017}}
$$

The calculated values of the coefficients are listed in Table 2.

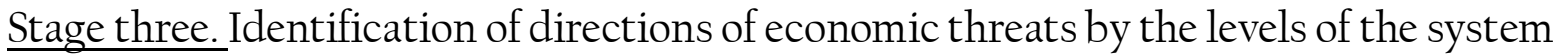
of indicators, including particular criteria.

It was revealed on the basis of the obtained data of the financial security coefficient that the level of security stability in 2018 is significantly lower than the level of 2017 and it decreased from 1.142 to 0.942 . 
REVISTA DE LA UNIVERSIDAD DEL ZULIA. 3ª época. Año 12 N 32, 2021

Gamlet Y. Ostaev et al. // Development of a methodology for determining the financial security ... 70-86

This means that there is an increase in risks and threats, which manifested themselves to a greater extent in group 3 , then in group 4 , group 2 . The situation is positive in the first group, but the district administration should pay attention to improving the quality of budget planning and the degree of transparency of the budget process.

Table 2 - Calculation of private, group and integral coefficients of financial security of rural areas using the example of Balezinsky district

\begin{tabular}{|c|c|c|}
\hline \multirow{2}{*}{\multicolumn{3}{|c|}{ 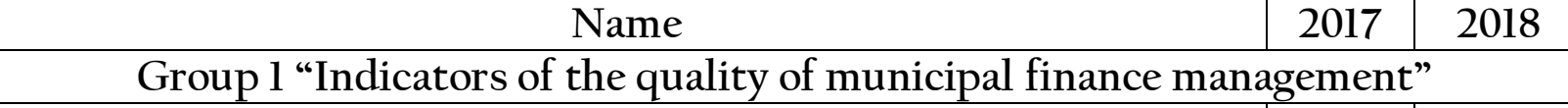 }} \\
\hline & & \\
\hline 1.1. Quality of budget planning & 1,026 & 0,800 \\
\hline 1.2. Quality of budget execution & 1,298 & 0,866 \\
\hline 1.3. Debt management quality & 1,092 & 0,999 \\
\hline $\begin{array}{l}\text { 1.4. The quality of municipal property management and the provision } \\
\text { of municipal services }\end{array}$ & 1,163 & 1,007 \\
\hline 1.5. Transparency of $t$ & 1,296 & 0,812 \\
\hline $\begin{array}{l}\text { 1.6. Implementation of the decrees of the President of the Russian } \\
\text { Federation of } 05 / 07 / 12\end{array}$ & 0,779 & 1,392 \\
\hline 1.7. Organization of financial control and audit & 0,935 & 1,389 \\
\hline Group coefficient $\mathrm{Kl}$ & 1,069 & 1,013 \\
\hline \multicolumn{3}{|c|}{$\begin{array}{c}\text { Group } 2 \text { "Indicators of economic development of the municipality (financial results } \\
\text { and objects of taxation)" }\end{array}$} \\
\hline $\begin{array}{l}\text { 2.l. The ratio of the revenue and expenditure parts of the municipal } \\
\text { budget }\end{array}$ & 1,010 & 1,031 \\
\hline $\begin{array}{l}\text { 2.2. The share of tax and non-tax revenues of the local budget in the } \\
\text { total volume of own revenues of the budget of the municipal formation }\end{array}$ & 0,894 & 1,221 \\
\hline $\begin{array}{l}\text { 2.3. Share of fixed assets of organizations of municipal ownership that } \\
\text { are in the stage of bankruptcy }\end{array}$ & 1,000 & 1,000 \\
\hline 2.4. The volume of investments in fixed assets per capita & 1,731 & 0,619 \\
\hline $\begin{array}{l}\text { 2.5. The share of the area of land plots that are objects of land taxation } \\
\text { in the total area of the district }\end{array}$ & 0,997 & 1,015 \\
\hline 2.6. Average monthly nominal accrued wages & 1,097 & 1,132 \\
\hline Group coefficient K2 & 1,093 & 0,982 \\
\hline
\end{tabular}


REVISTA DE LA UNIVERSIDAD DEL ZULIA. 3época. Año 12 N 32, 2021

Gamlet Y. Ostaev et al. // Development of a methodology for determining the financial security ... 70-86

DOI: http://dx.doi.org/10.46925//rdluz.32.06

\begin{tabular}{|c|c|c|}
\hline \multicolumn{3}{|c|}{$\begin{array}{c}\text { Group } 3 \text { "Financial indicators of entrepreneurial activity of large, medium-sized } \\
\text { organizations and small enterprises" }\end{array}$} \\
\hline 3.1. Amount of funds allocated to support SMEs & 14,635 & 1,425 \\
\hline 3.2. Property value of organizations & 1,037 & 0,889 \\
\hline 3.3. Capital and reserves of organizations & 1,098 & 1,102 \\
\hline 3.4. Balanced financial result of organizations' activities & 1,063 & 0,532 \\
\hline 3.5. Share of unprofitable organizations & 1,748 & 0,310 \\
\hline 3.6. The amount of losses received by organizations & 0,440 & 1,218 \\
\hline 3.7. The excess of accounts payable over accounts receivable & 1,621 & 0,570 \\
\hline 3.8. Costs per 1 ruble of sales revenue & 1,032 & 0,939 \\
\hline 3.9. Profitability of sold goods, products, works, services of organizations & 2,000 & 0,088 \\
\hline 3.10. Profitability of all assets of organizations & 1,032 & 0,594 \\
\hline 3.1l. Organizational autonomy ratio & 1,058 & 1,240 \\
\hline 3.12. Ownership ratio & 4,000 & 2,863 \\
\hline working capital of organizations & 1,240 & 1,225 \\
\hline 3.13. Current liquidity ratio of organizations & 1,528 & 0,771 \\
\hline \multicolumn{3}{|c|}{ Group 4 "Financial indicators of the efficiency of agricultural production" } \\
\hline 4.1. Milk production efficiency & 0,973 & 0,934 \\
\hline 4.2. Production efficiency of cattle gain & 1,017 & 0,949 \\
\hline 4.3. Grain production efficiency & 1,022 & 0,963 \\
\hline 4.4. Potato production efficiency & 0,998 & 1,020 \\
\hline 4.5. Efficiency of production and sales of products in general & 0,998 & 0,954 \\
\hline 4.6. Share of profitable agricultural organizations & 0,933 & 0,929 \\
\hline 4.7. Profit before tax per employee, thousand rubles & 1,635 & 0,270 \\
\hline 4.8. Taxes paid per hectare of agricultural land, thousand rubles & 0,899 & 1,042 \\
\hline 4.9. Agricultural products sold for 1 ruble of state support, rubles & 1,198 & 0,960 \\
\hline 4.10. Profit volume for 1 ruble of state support, rubles & 1,789 & 0,250 \\
\hline Group coefficient K4 & 1,010 & 0,973 \\
\hline $\begin{array}{l}\text { Integral indicator of financial security of Balezinsky district } \\
\mathrm{K}_{\text {fin_security }}=\mathrm{Kl} \cdot 0,2+\mathrm{K} 2 \cdot 0,2+\mathrm{K} 3 \cdot 0,2+\mathrm{K} 4 \cdot 0,4\end{array}$ & 1,142 & 0,942 \\
\hline
\end{tabular}

*Authoring 


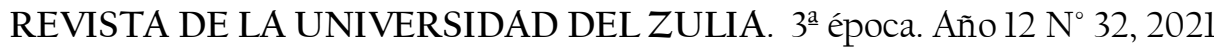

Gamlet Y. Ostaev et al. // Development of a methodology for determining the financial security ... 70-86

DOI: http://dx.doi.org/10.46925//rdluz.32.06

Table 3 - Systematization of parameters by types of threats to financial security

\begin{tabular}{|c|c|}
\hline $\begin{array}{l}\text { The level of economic } \\
\text { security by the degree of } \\
\text { threats }\end{array}$ & $\begin{array}{l}\text { Parameter (value of the private coefficient of financial } \\
\text { security) }\end{array}$ \\
\hline $\begin{array}{c}\geq 1,0 \\
\text { sustainable security }\end{array}$ & $\begin{array}{l}83 \% \text { of the parameters of group } 1 \text { "Indicators of the quality } \\
\text { of municipal finance management" } \\
57 \% \text { of the parameters of group } 2 \text { "Indicators of the } \\
\text { economic development of the municipality" } \\
\text { For other groups, insignificant 1-3 parameters have a safe } \\
\text { state }\end{array}$ \\
\hline $\begin{array}{c}0,96-0,99 \\
\text { initial stage of threats }\end{array}$ & $\begin{array}{l}\text { 4.9. Agricultural products sold per } 1 \text { ruble of state support } \\
(0.960) \\
\text { 4.3. The ratio of revenue to the total cost of production and } \\
\text { sale of grain }(0.964)\end{array}$ \\
\hline $\begin{array}{c}0,91-0,95 \\
\text { developing stage of threats }\end{array}$ & $\begin{array}{l}\text { 4.6. Share of profitable agricultural organizations in their } \\
\text { total number }(0.929) \\
\text { 4.l. Ratio of revenue to total cost of milk production and } \\
\text { sales }(0.934) \\
\text { 3.8. Costs per ruble of revenue of large and medium-sized } \\
\text { enterprises ( } 0.939) \\
\text { 4.2. The ratio of revenue to the total cost of production and } \\
\text { sales of the increase in workover }(0.949) \\
\text { 4.5. The ratio of proceeds to the total cost of production of } \\
\text { all agricultural products }(0.954)\end{array}$ \\
\hline $\begin{array}{l}0,81-0,90 \\
\text { critical stage }\end{array}$ & $\begin{array}{l}\text { 1.5. Indicators characterizing the degree of transparency of } \\
\text { the budget process }(0.812) \\
\text { 1.2. Indicators characterizing the quality of budget } \\
\text { execution }(0.866) \\
\text { 3.2. Property value of large and medium-sized } \\
\text { organizations }(0.889)\end{array}$ \\
\hline $\begin{array}{c}0,71-0,80 \\
\text { unstable stage }\end{array}$ & $\begin{array}{l}\text { 1.1. Indicators characterizing the quality of budget } \\
\text { planning }(0.800)\end{array}$ \\
\hline $\begin{array}{l}0,61-0,70 \\
\text { threatening stage }\end{array}$ & $\begin{array}{l}\text { 2.4. Investment in fixed assets (excluding budget funds) } \\
\text { per capita (0.619) }\end{array}$ \\
\hline $\begin{array}{c}\leq 0,60 \\
\text { emergency stage }\end{array}$ & $\begin{array}{l}\text { 3.9. Profitability of sold goods, products, works, services of } \\
\text { organizations }(0.088) \\
\text { 4.10. The amount of profit per } 1 \text { ruble of state support in } \\
\text { agriculture }(0.250) \\
\text { 4.7. Profit before tax per l worker in agriculture }(0.270) \\
\text { 3.5. Share of unprofitable organizations }(0.310) \\
\text { 3.4. Balanced financial result }(0.532) \\
\text { 3.7. The excess of accounts payable over accounts } \\
\text { receivable ( } 0.570) \\
\text { 3.10. Return on all assets of organizations }(0.594)\end{array}$ \\
\hline
\end{tabular}

*Authoring 


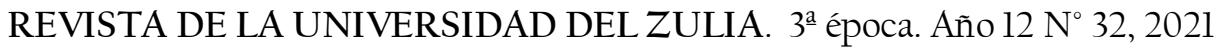

Gamlet Y. Ostaev et al. // Development of a methodology for determining the financial security ... 70-86 DOI: http://dx.doi.org/10.46925//rdluz.32.06

It can be argued that the greatest problems (risks and threats) are manifested in the production spheres of the economy of the Balezinsky district:

-7 out of 13 (54\%) parameters for group 3 "Financial indicators of entrepreneurial activity of large, medium-sized organizations and small enterprises" characterize different levels of the crisis state of financial security. The group coefficient was 0.771 . In general, it is an unstable stage, when the business is in a zone of strong threats and urgent measures are required that the business community, together with municipal authorities, can solve on their own;

- only 2 indicators out of 10 in group 4 "Financial indicators of agricultural production efficiency" characterize the stability of economic security, but the rest of the parameters generally indicate a pre-crisis state, when violations and restrictions can still be removed with skillful operational management of business processes in agricultural production. The group coefficient was 0.973 .

Fourth stage. Justification of recommendations to improve economic security.

Considering that in 2018 the final financial safety factor was 0.942 , it is impossible to achieve the ideal level (more than 1 ) in a short time in modern realities.

On the basis of private coefficients of financial security, one can select especially significant problems in each group and formulate directions for strengthening financial security. The economy of Balezinsky district can become quite financially stable with detailed elaboration of measures for each problem area.

\section{Conclusions}

The analysis of the economic development of rural areas is carried out on the example of the Balezinsky district of the Udmurt Republic. The analysis showed that the socioeconomic situation of the district is experiencing certain risks and threats to economic security: an unfavorable demographic situation, an increase in unemployment, a decrease in production volumes, etc.

The proposed systematization of economic development indicators, and the calculation of integral and private indicators of the financial security of the territory using the principles of qualimetry (the science of measuring quality) will help determine financial indicators in 


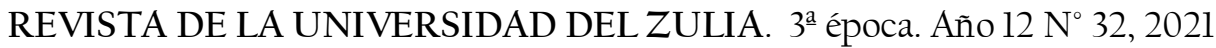

Gamlet Y. Ostaev et al. // Development of a methodology for determining the financial security ... 70-86 DOI: http://dx.doi.org/10.46925//rdluz.32.06

assessing the economic security of not only one district of the Udmurt Republic, but also other rural areas of the country.

\section{References}

Alborov R.A., Kontsevoy G.R. (2016). Strategic performance assessment. Strategic development of socio-economic systems in the region, pp. 17-21. An innovative approach Materials of the II international scientific and practical conference. General edition: Skuba R.V., Barinov M.A.; Vladimir State University named after Alexander Grigorievich and Nikolai Grigorievich Stoletovs.

Alekseeva N.A. (2020). Regional dimensions of macroeconomic indicators. Development of accounting, analysis and audit in the context of the digitalization of the economy, pp. 129133. Materials of the All-Russian Scientific and Practical Conference.

Botkin O.I., Nekrasov V.I., Gogolev I.M., Botkin I.O. (2020). Dynamics of development of interbudgetary relations in the region. Regional economy problems (Izhevsk). 1-2: 102-120.

Endovitsky D.A., Durakova I.B. (2018). Statistical analysis as the basis for the practice of modernizing personnel management: international experience. International Journal of Engineering and Technology (UAE). 7(4): 145-15l.

Endovitsky D.A., Lyubushin N.P., Babicheva N.E., Zotova E.S. (2019). Assessment of the balance of economic entities' activity at different life cycle stages. Montenegrin Journal of Economics. 15(2):71-79.

Frantsisko O.Yu., Ternavshchenko K.O., Molchan A.S., Ostaev G.Ya., Ovcharenko N.A., Balashova I.V. (2020). Formation of an integrated system for monitoring the food security of the region. Amazonia Investiga, 9(25):59-70.

Gogolev I.M., Abramova K.Yu., Lebedev N.S. (2020). Production and economic assessment of regional land use. Land use efficiency management, pp. 73-79. Materials of the II National Scientific and Practical Conference.

Kondratyev D.V., Osipov A.K., Gainutdinova E.A. (2019). Optimal management of investments in the development and intensification of the use of land resources in agriculture. Basic research. 4: 43-47.

Kondratiev D.V., Ostaev G.Ya., Osipov A.K., Bogomolova T.P., Nekrasova E.V., Abasheva O.V. (2020). Organizational and management mechanism for reforming agricultural organizations based on cooperation and integration of economic systems. Amazonia Investiga. 9(25): 376-388.

Kontsevaya S.R. (2017). Analysis and control of government subsidies for investments in agriculture of the Russian federation Acta Scientiarum Polonorum. Hortorum Cultus. $16(3): 25-33$. 
REVISTA DE LA UNIVERSIDAD DEL ZULIA. 3ª época. Año 12 N³2, 2021

Gamlet Y. Ostaev et al. // Development of a methodology for determining the financial security ... 70-86

DOI: http://dx.doi.org/10.46925//rdluz.32.06

Kontsevaya S.R., Chachotkin S., Kostina R.V., Khoruziy L. (2019). Ranking score of financial condition and fear of bankruptcy to evaluate operation's continuity of dairy milk processing companies: evidence from the republic of Belarus, pp. 422-430. Hradec Economic Days Double-blind peer-reviewed proceedings part I. of the international scientific conference Hradec Economic Days.

Krivorotov V.V., Kalina A.V., Eriashvili N.D. (2015). Economic security of the state and regions. Moscow: UNITI-DANA. Available from: http://www.iprbookshop.ru/52598.html.

Markovina E.V., Mukhina I.A., Bessogonova N.V. (2020). Integration principles of management of investment security of an agricultural organization. Scientific innovations in the development of agricultural sectors. Materials of the International Scientific and Practical Conference. 3:174-179.

Molchan A. S., Frantsisko O. Yu., Ternavshchenko K. O., Illaronova V. V., Prokhorova V.V. (2017). Organizational Structure of Agro-Industrial Complex: Formation and Interaction of Subjects. International Joumal of Applied Business and Economic Research. 15(23): 281-296.

Molchan A.S., Frantsisko O.Yu., Ternavshchenko K.O., Ostaev G.Ya., Tinyakova V.I., Markovina E.V. (2020). Optimization of interaction of agrarian entities as an imperative of ensuring food security of the state. Amazonia Investiga, 26: 242-253.

Mukhina I.A. (2018). Implementation of the provisions of qualimetry in assessing the quality of state and municipal administration. Management: theory and practice. S: 69-71.

Mukhin A., Konina E., Gorbushina N., Latysheva A. (2020). Modeling of production processes in rural areas: management and development effectiveness. Amazonia Investiga, 9(29):179-187.

Mukhin A.A., Mukhin I.A. (2018). Methods for assessing the sustainability of the financial security of the region. Modern problems of economic development and management in the region (in the context of digital transformation), pp. 414-419. Materials of the XI International Scientific and Practical Conference. Branch of the St. Petersburg Institute of Foreign Economic Relations, Economics and Law in Perm.

Mukhina I., Ostaev G., Sokolov V., Markovina E. (2020). Migration processes in rural areas as an indicator of economic security Amazonia Investiga. 9(28): 330-337.

Ostaev G., Khosiev B., Nekrasova E., Frantsisko O., Markovina E., Kubatieva L. (2019). Improving the methodology for assessing the efficiency of labor in organizations of the agroindustrial complex: strategic accounting and analysis. Indo American Journal of Pharmaceutical Sciences. 06(05): 9114-9120.

Ostaev G.Ya., Klychova G.S., Nekrasova E.V. (2018). Making managerial decisions: mechanisms and financial instruments. Bulletin of Kazan State Agrarian University. 13. 4 (51): 146-152.

Sheremet A.D. (2009). Analysis and diagnostics of the financial and economic activity of the enterprise. Moscow: INFRA-M. 